\title{
Stabilizing Between Work And Family: Professional Mothers' Struggle To Achieve Success
}

\author{
Shagufta Nasreen \\ \& \\ Aliyah Ali \\ Women's Studies Centre \\ University of Karachi \\ Faraz Ahmed Wajidi \\ National Bank of Pakistan
}

\begin{abstract}
Paid work and family life adjustment has attracted attention of researchers for quite a long time. The gender division of labour has been changed in many societies due to social, political and economic factors. The aim of this study was to explore the level of satisfaction and strategy patterns of professional mothers in socialization of their children. The study has used quantitative and qualitative data collection tools. Sixty professional mothers were interviewed from various professions using purposive sampling method. $78 \%$ of respondents said that they are satisfied with their children's education and personality development. It is recommended that government should provide day-care facilities at workplace for women workers so that they can focus on their work effectively.
\end{abstract}

Keywords: Professional Mothers', Work \& Family.

$$
\begin{aligned}
& \text { تلخيص }
\end{aligned}
$$

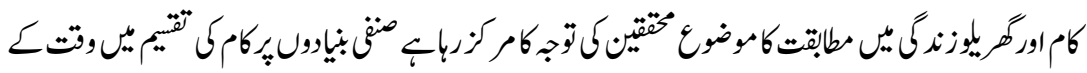

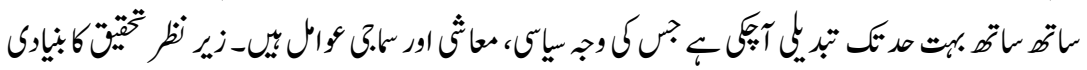

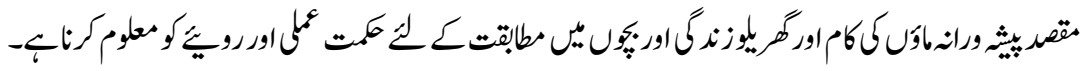

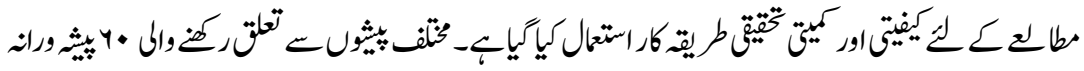

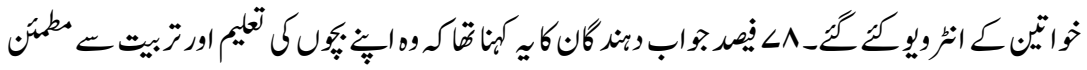

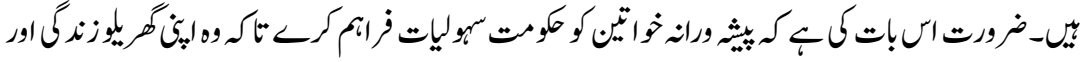

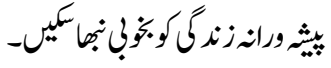

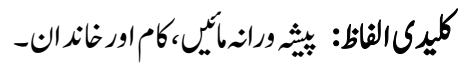

She never quite leaves her children alone at home, even when she doesn't take them alone. (Margerat Culkin Banning)

Balance between time and priorities leads to success. (A Doctor) 
A good domestic life is essential for success in professional life. (A Teacher)

\section{Introduction}

The fundamental unit of each society is the family. Families make up the structure of each group and ought to be esteemed for the essential part they hold in keeping individuals together. The leaders of each familial unit have an obligation. Usually, it father's primary role is considered to be breadwinner - working seven days to oblige his family financially. The mother is assigned role of the homemaker managing the children and the house. In contemporary world, changing poltical, economic and social structures has altered the supposedly 'natural' roles of men and women. Karaim (2003) observe that father accept a more unique part in the lives of his children and in the running of the family. The mother has become more unique outside of the home, much of the time by working. However, the changing roles have faced acceptance and rejection with respect to the interest and consequences of having women work outside of the home (Karaim, 2003).

It is achievable to be a woman, a mother, and a career woman. Many have done it with the help of society, and others have battled unending opportunities to exhibit the same. Nowadays it is both, charming and officeholder upon mothers to be working, like their counterparts. Still, in many societies it is perceived that women's primary role is to take care of children and working mothers are unable to fulfil that responsibility. While researchers argue that 'a working mother is not a not too bad mother, a working mother can, really, be a better mother' ( Poduval \& Poduval, 2009).

Another area of concern related to working mothers is place of women's paid work. Inside this broad term, concealed are two interesting measures of working women: the homemaker who works from home and the woman who works a long way from home while making sense of how to fulfil her maternal commitments. The World is changing and women are becoming part of paid jobs especially in the period of recessions creating unemployment among men at a higher rate than women (Hirshman, 2006; Sayer et al., 2004).

Even though, the concept of paid work has been acknowledged nevertheless she herself and the society try to attest the change of role. The working mother tries to keep the persuading position that she is working for her own sustenance, as well as for the improvement of the family. Something like, "a working woman who put herself out for the child's purpose". Although justifying "working" takes away a great part of the issues a working mother needs to confront (Wilson, 2006).

Working women who become mothers often face difficult situations during their career as whether or not they continue their employment, moreover part-time or 
full-time, and where she left her child during her working hours. National policies regarding family, behaviour of society and parental preferences influence mothers' decision to continue work or not. Therefore, decision of mothers' employment is not only dependent on child care decision. Finally employment conditions and child care need to be managed to return to the labour market.

Many researches prove that the way that data and investigation of working moms, and of class qualifications among working moms, is inadequate. It likewise indicates the presence of a division of thought and depiction regarding working moms that is of genuine concern, Doing, clothing, vacuuming, and cleaning washrooms should be possible late during the evening, at a young hour in the morning, or quickly put off. 'They feel a sense of empowerment. If they're earning money, they feel that disaster is less likely to hit them." (USA Today, 2000)

The subject of women's work at home and outside needs to be seen from husband's perspective as well. Why do most spouses see the unbalanced division of residential work in their families as reasonable?' First, women don't esteem family work for the errands themselves, yet for the feeling of achievement they feel for dealing with a home well. There is a sure measure of energy that accumulates to working moms who manage family life. Likewise, working moms accomplish a feeling of gender difference affirmation for function admirably done. While family unit administration duties may affect working moms, family unit requests are more effortlessly masterminded than child care thus the anxiety is normally not as great. Similarly, maybe doing enthusiastic work is not related with seen push since women, paying little respect to business status, are associated to view feeling fill in as fundamentally the obligation of females. They may take pride in direct correspondence, social-passionate upkeep in the relationship, and their office at going up against issues, communicating warmth, and taking part in self revelation. Most working mothers have an assertive, active sense of their emotional labor. To increase mother's labor force participation three developments were essential a) demographic trends such as increasing multiplicity of families and workplaces and the inactivity of mothers' labor force participation. Researchers paid attention to the topics of gender, time and division of labor. In the 2000 - 2010 decade, various reviews demonstrated that men's and women' distribution of time to paid and unpaid work had turned out to be more comparable, with the gender gap crevice in the unpaid work of cooking, cleaning, and child care narrowing considerably. The littler gender gap in housework was an after effect of an expansion in men's time, additionally a vast decrease in women' chance in these exercises. As for child care, all the narrowing was a direct result of an expansion in men's chance with their children: Beginning in the mid1980s, married fathers' opportunity to spent time with their kids started to increment (Bianchi et al., 2006). 
All investigations of housework gave confirm on a set number of causal clarifications for men's generally low commitment - the time accessibility clarification, the relative assets record, or some variation of the gender gap point of view that accentuated either the part of gender ideology or the possibility of housework as "doing gender." Despite the vast number of studies, there rose no prevailing accord on the most powerful clarification for the diligence of the gender division of work in the home. Asserting that men's and women's paid and unpaid work was meeting underscored discerning basic leadership and time accessibility as the key clarification (Sayer, 2005).

The term enthusiastic care work is utilized to highlight the emotional and uncomodifiable part of moms' minding in instruction. Enthusiastic care work includes a relationship that is substantively distinctive. Lynch (1989) distinguished 'love work' as passionate care work performed inside cozy connections, a work that is other coordinated or heteronymous (Jaggar, 1995; Kittay and Feder, 2001), and a basic work, essentially involved in cultivating the relationship in essence. Lynch proposes that this kind of care work is extraordinary in light of the fact that you can't, for instance, pay somebody to eat with your accomplice 'as though it was you', or in this occurrence, to take choices about your child's care and tutoring, 'as though it was you' your nearness is required for the relationship to work.

Others have proposed that male engagement in customary instructive care work is additionally classed, and that white collar class men have more assets/capitals that enable them to get required in supporting a few parts of their youngsters' training. Without a doubt, leading the pack in basic leadership at pivotal instructive circumstances can be viewed as a major aspect of the status of working class. However, David et al. (1994) inside and out investigation of family procedures required in picking auxiliary schools, found while choices were frequently observed as the duty of moms, that fathers were regularly required to fluctuating degrees. This was connected to race or potentially gender of the child, however not especially to class. With respect to their material, social and passionate substances, moms share a typical view that tending to kids and their training is a need. Not to care implies not to love, and given that there are no options inside talks of care, not to love would be practically unimaginable and profoundly unethical for a mother (Brien, 2007).

Most people experience an arrangement of clashing feelings, intentions, and needs as they travel through life. Since women are particularly subject to auxiliary uncertainty in which they should pick between contrary objectives. Among the group of passionate women encounter from "fear of accomplishment" to "dread of disappointment" or from the "need to sustain" to the "need to accomplish" nobody feeling decides conduct. Or maybe, as women battle with clashing feelings, they 
will conquer a few and follow up on others. Their decisions are in this manner more inclined to mirror the blend of basic requirements and openings accessible to them when basic life choices are made than to speak to the destined unfurling of their "woman like identities" or the declaration of a uniform and unmistakably female voice (Gerson, 1985). In the greater part of the world in many times of history, women have made an essential, guide commitment to the financial support of the family. This commitment has quite often incorporated the handling of nourishment and fiber, and the cleaning and requesting of utensils, garments and abiding (Hoffman, 1975).

Until the point when present day times, lawful furthermore, social practices, solidified with the dormancy of longstanding religious and informational conventions, restricted women' passageway and enthusiasm for the workforce. Money related dependence upon men, and accordingly the poor monetary status of women, has had a comparable impact, particularly as occupations have pushed toward getting to be professionalized over the nineteenth and twentieth century (Attanayake).

Also, more settled family who deal with more energetic kinfolk set aside a few minutes and space for mothers to return to the work drive (Birch, 2005). Then again, having at least three kids can make more noteworthy disturbance moms' work directions than having two kids. The previous gathering of moms leave their pre-maternity employments more circumstances spend longer out of the workforce and are additionally more prone to have bring down pre-maternity engagement with the formal workforce (Karin \& Rindfuss, 2000). Domestic work incorporates: (a) housework, for example, cooking, doing clothing, and cleaning the house; (b) child care; and, all the more as of late scientists have widened the definition to coordinate (c) passionate work. Enthusiastic work or feeling work was to get the work normally done by women to share by and by with associates, regulate conflicts, and keep up the relationship. To the extent that working mothers join paid work with family responsibilities, and in addition have critical commitment in regards to nearby work, juggling different parts may well incite work-family battle, part finished weight, and stress. Late research demonstrates stress is most noteworthy among working moms when requests are high at both work and home.' "When part over-burden happens, the constructive outcomes of work for working moms are alleviated. Working moms offer recedence to their family characters when work-family clashes emerge, while fathers have a tendency to be more work focused in their personality.

The topic of work-life adjust is generally viewed as being less demanding for expert and administrative women. Beyond any doubt women and men in expert and administrative occupations improve work life privileges from their bosses. All the more especially, profoundly taught (administrative and proficient) 
women work longer hours than women in the lower word related groupings. Working hours have been exhibited to be the central point related with levels of work life weight. Administrative and proficient women work longer hours than women in the lower word related groupings. Administrative and proficient women, notwithstanding when they work all day more often than not assume liability for the larger part of childcare and local work in their family unit (Scott et al., 2008).

Despite the fact that both men and women are members in the work showcase their relationship to the foundation of home has contrasts in its effect and impact and subsequently in the level of flexibility of work cooperation also (Mangas \&Marcos, 2008).

Parenthood may have a long reach for the duration of women' lives, yet this examination has demonstrated that its effect on women's' vocations lessens over the life course. Kids lessen work compel cooperation, yet this impact is most grounded when women are more youthful, in their 30s, when their kids are more youthful as well. Sometime down the road, as kids age, there might be counter weights for moms to build their work supply to meet the monetary needs of more established kids. Though earlier research has by and largely overlooked choice into the work constraint and essentially evaluated wage punishments among working women, we particularly tried for a parenthood crevice in business. The prizes of moms' vocations, both regarding compensation and work related status, likewise seem to recover ground as women age into their 50s, however with a few contracts by equality. Though moms with at least three youngsters keep on suffering huge wage punishments of no less than $4 \%$ for each child ways into their $50 \mathrm{~s}$, bring down equality moms have by and large limited the wage crevice with childless women by their 40s. Actually, comes about propose that having just a single child never fundamentally harms a mother's wages (Kahn et al., 2014).

\section{Working Women in Pakistan}

Women in the workforce earning wages or a compensation are a piece of a cutting edge wonder, one that created in the meantime as the development of paid work for men, yet women have been tested by disparity in the workforce. Until the point that cutting edge times, legitimate and social practices, consolidated with the dormancy of longstanding religious and instructive traditions, limited women' entrance and interest in the workforce. Monetary reliance upon men, and thusly the poor financial status of women, has had a similar effect, especially as occupations have progressed toward becoming professionalized over the nineteenth and twentieth hundreds of years (Attanayake).

In Pakistan a new culture is developing swiftly. Women have been seen making improvement in each division of life. Pakistan's female populace is evaluated to 
be 48.65 percent of the aggregate, the dominant part of which lives in the nation's country regions. In rural Pakistan open doors for women are still lower than those the restricted ones for their sisters in the urban focuses. As per Labor Force Statistics (LFS) 2012-2013, of the assessed 180 million individuals, just 12.51 million Pakistani females of different ages are in work or the like (Mirza, 2014).

\section{Karachi}

Karachi is main financial hub of Pakistan. The cosmopolitan city is providing financial assistance to every citizen. In Karachi women are leading a prominent working role. The trend of mothers' employment is increasing day by day.

In this regard mothers said that increasing inflation had made it compulsory for the mothers to get a suitable employment. The expenses of daily routine cannot be met easily without the job of mothers. Moreover, mothers do job for the sake of better education and training of their children. Students and teachers mutually expressed that working of mother and father jointly has become very essential for the family expenses (Almani, et al., 2012) however women who are doing multiple tasks with a little support from their husbands or families are burdened more than mothers stayed at home.

\section{Objectives}

- To find out strategy and behaviour patterns of professional mothers towards their children.

- To find out satisfaction of professional mothers and their children towards each other

- To find out does communication gap between mother-child relationships exists.

\section{Questions}

The study of role of a mother in upbringing a child in today's times is very important because the number of married working women is increasing day by day. It's difficult to fulfil both roles a full professional and a good mother also. Therefore the proposed study aims to find out issues of professional mothers in fulfilling their roles. Professional mothers have to do much in their short time because they don't have enough time to spend with their children. This sometimes creates dissatisfaction among mothers and children and develops communication gap in mother-child relationship. Furthermore, professional mother faces more burdens in maintaining balance between her professional and personal life. This research study examines does professional mother remains successful in fulfilling her multiple roles especially concerned to her children. 


\section{Hypothesis}

1. Professional mothers play better role in upbringing their children because of their active role in society.

2. Professional mothers usually have less communication gap.

3. Professional mothers bear and face a lot of difficulties in life including playing a role in upbringing their children.

4.

\section{Methodology}

The study has used quantitative and qualitative data collection tools; which help identifying the research problem in a particular social, cultural and historical back ground. The methods used in this study are based on structured interviews. Interviews are taken from professional mothers at executive posts. Sixty professional mothers are interviewed from various professions like teachers, doctors, engineers, managerial posts, principals and media person's. 10 women are selected from each profession mentioned. A purposive sampling strategy has used for research; a snowball strategy emerges subsequently.

\section{Results and Discussion}

Table: 1

Distribution according to satisfaction towards education and training of children

\begin{tabular}{|l|c|c|}
\hline Satisfied & Frequency & Percentage \\
\hline Yes & 47 & $78 \%$ \\
\hline No & 1 & $2 \%$ \\
\hline To some extent & 12 & 20 \\
\hline Total & $\mathbf{6 0}$ & $\mathbf{1 0 0 \%}$ \\
\hline
\end{tabular}

$78 \%$ of respondents said that they are satisfied with their children's education and training. Usually it is perceived that women's double role may become a hindrance (Mangas \& Marcos, 2008) in giving attention to her children. The study confirms the finding (Sayer et al., 2004) that mothers doing paid job are more concerned with the education and training of their children. During research respondents showed that because they are aware of issues children are facing these days they focus on their children accordingly. Hence, $20 \%$ women were satisfied to some extent because work needs their attention therefore they have less time for their children. Although contemporary moms, pay little attention to their work status, really invest more energy with their children than moms did in previous twenty years when they were more averse to be utilized. In addition, moms' paid work may build the monetary assets that families can commit to their kids' effective advancement. 
Table: 2

Distribution according to reasons of doing job

\begin{tabular}{|l|c|c|}
\hline Reason & Frequency & Percentage \\
\hline To provide good education to children & 26 & $43 \%$ \\
\hline For family & 06 & $10 \%$ \\
\hline Personal interest & 22 & $37 \%$ \\
\hline Above all & 6 & $10 \%$ \\
\hline Total & $\mathbf{6 0}$ & $\mathbf{1 0 0 \%}$ \\
\hline
\end{tabular}

Table no. 2 shows that $43 \%$ moms were doing job to earn extra income to provide good education to their children. People have realized the importance of quality education for the children. In Pakistan, high quality education is quite expensive and unaffordable for majority of people. Therefore, these mothers are also playing a significant role in providing better educational facility to the children. $37 \%$ on the other hand showed interest in satisfying their own interest for jobs. They wanted to get professional experience and advance their career goals.

Table: 3

Distribution according to allocation of time for children personality development

\begin{tabular}{|l|c|c|}
\hline Estimated Time & Frequency & Percentage \\
\hline Two hours & 10 & $17 \%$ \\
\hline Three hours & 20 & $33 \%$ \\
\hline Four hours & 30 & $50 \%$ \\
\hline Total & $\mathbf{6 0}$ & $\mathbf{1 0 0 \%}$ \\
\hline
\end{tabular}

Although it's very difficult to measure women's time they spent towards their reproductive responsibilities however, researcher tried to do measurement and according to table no.3, 50\% respondents said that they spent almost four hours with their children. After job their all time is reserved for their children. 33\% of respondents said that they have 3 hours to give to their children. The respondents also said that children are well aware of good and bad and positive environment and education is essential for child personality development. The study confirms that earlier studies on parental sentiments of not investing enough time with kids were far reaching and higher for fathers who spent more hours from home in the paid workforce than moms (Milkie et al., 2004). Sentiments of time shortages with youngsters were all the more contrarily associated with measures of prosperity among moms than fathers (Nomaguchi etal, 2005). Families longed for excellent "family time" that was longed for astounding "family time" that was hard to accomplish practically speaking (Daly, 2001), hard to accomplish (Schneider, 2006). Although the work and family field was ruled by the presumption that "excessively" work was the real issue in adjusting the requirement of family life, there was expanded regard for the way that "too little" work was additionally a noteworthy work-family issue (Jacobs \& Gerson, 2004). 
Table: 4

Distribution of respondents according to children feeling proud

\begin{tabular}{|l|c|c|}
\hline & Frequency & Percentage \\
\hline Yes & 55 & $92 \%$ \\
\hline No & 05 & $8 \%$ \\
\hline Total & $\mathbf{6 0}$ & $\mathbf{1 0 0 \%}$ \\
\hline
\end{tabular}

Majority of children of professional mothers felt proud of them showing a shift of perceptions about female employment. Earlier studies showed that family and children were not happy with female's job. Changing economic conditions, government efforts for women and development have been able to change societal attitude towards female employment. Therefore it is more important now to provide her facilities which help her to fulfil her responsibilities effectively for example taking care of children, maternity leave flexible working hours and so on.

Table: 5

Distribution according to communication with mothers

\begin{tabular}{|l|c|c|}
\hline Communication & Frequency & Percentage \\
\hline Share full day activities & 38 & $63 \%$ \\
\hline Share friends matters & 07 & $12 \%$ \\
\hline Future plans & 05 & $08 \%$ \\
\hline Above all & 10 & $17 \%$ \\
\hline Total & $\mathbf{6 0}$ & $\mathbf{1 0 0 \%}$ \\
\hline
\end{tabular}

The result shows that $63 \%$ respondents share their full day activities with their mothers which prove that children are close to their mothers. Children usually share their daily routine, friends matters and future plans with mothers.

Table: 6

Distribution of respondents according to management of issues between professional life and household

\begin{tabular}{|l|c|c|}
\hline Management & Frequency & Percentage \\
\hline Can't have time for family & 16 & $27 \%$ \\
\hline $\begin{array}{l}\text { Children personality } \\
\text { development is affected }\end{array}$ & 06 & $10 \%$ \\
\hline Can't have time for husband & 04 & $7 \%$ \\
\hline Above all & 04 & $7 \%$ \\
\hline Manage both work and family & 19 & $32 \%$ \\
\hline Take timeout to myself & 11 & $18 \%$ \\
\hline Total & $\mathbf{6 0}$ & $\mathbf{1 0 0 \%}$ \\
\hline
\end{tabular}


$32 \%$ of respondents said that they can easily manage both work and family, whether $27 \%$ respondents said that due to their professional responsibilities they cannot have time for their families. Another interesting answer by $18 \%$ respondents is that they are successful in taking time out for themselves to enjoy. The results show that working mothers are disturbed due to their professional responsibilities which affect their family life.

\section{Conclusions}

The study measured the level of satisfaction of working women of formal sector towards their responsibilities of home and children. It was observed that gender inequality, care of children and socialization of children are the major challenges faced by professional mothers, on the other hand good salary and facilities, encouragement from the family and support of husband are the major factors to decrease their problems. To fulfil her role effectively, a mother needs stress free environment which can be created by provided by institutions as day-care facilities at work place so that she can focus on her work and it will lead to increase her productivity.

\section{Recommendations}

- Government and private sector should provide day-care centre facilities for professional mothers.

- Flexible working hour's policy may be adopted in private sector.

- Attitude and behavior of society needs to be changed especially regarding the nurturing and socialization of children.

- Media can play an important role by featuring the real issues of working mothers despite projecting her as a super woman.

\section{References}

Almani, A.S., Abro, A. \& Mugheri, R.A. (2012). Study of the Effects of Working Mothers on the Development of Children in Pakistan, International Journal of Humanities and Social Science, vol.2:11, http://www.ijhssnet.com/journals/Vol_2_No_11_June_2012/18.pdf

Attanayake, Shamini, M.T.R. Women at Work-Place- Gender Sensitivity, Work Life Balance and Empowerment. http://www.academia.edu/15349575/ Women_at_workplace-_gender_sensitivity_work-life_balance_and_ empowerment

Bianchi, S. M., Robinson, J. P. \& Milkie, M. A. (2006). Changing Rhythms of American Family Life. New York: Russell Sage Foundation. 
Bittman, M. \& Wajcman, J. (2000). The Rush Hour: The Character of Leisure Time and Gender Equity. Social Forces, vol.79, pp.165-189. Blair-Loy, M. (2001). Cultural Constructions of.

Blair-Loy, M. (2003). Competing Devotions: Career and Family among Women Executives. Cambridge, MA: Harvard University Press.

Daly, K. J. (2001). Deconstructing Family Time from Ideology to Lived Experience. Journal of Marriage and Family, vol.63, pp.283-294.

Gupta, S., Smock, P. J. \& Manning, W. D. (2004). Moving out: Transition to Nonresidence among Resident Fathers in the United States, 1968 - 1997. Journal of Marriage and Family, vol.66, pp.627-638.

Hirshman, L.R. Unleashing the Wrath of Stay-at-Home Moms. Washington Post, 2006. p.B01.

Jacobs, J. A. \& Gerson, K. (2004). The Time Divide: Work, Family, and Gender Inequality. Cambridge, MA: Harvard University Press.

Jacqueline Scott, Shirley Dex, \& Heather Joshi, (2008). Women and Employment, Changing Lives and New Challenges, Edward Elgar, MA, USA, pp.218231.

Kahn, Joan R., Javier García-Manglano, and Suzanne M. Bianchi (2014). The Motherhood Penalty at Midlife: Long-Term Effects of Children on Women's Careers. Journal of Marriage and Family, vol.76:1, pp.56-72, https://search.proquest.com/docview/1552460777?accountid=135034.

Karaim, Reed. "Working Mothers Are Benefiting the Family." Opposing Viewpoints: The Family. Ed. Auriana Ojeda. San Diego: Greenhaven Press, 2003. Opposing Viewpoints Resource Center. Gale. San Joaquin Delta College. 20 Mar. 2009.

Brewster, Karin L. \& Rindfuss, Ronald R. (2000). Fertility and Women's Employment in Industrialized Nations, Annual Review of Sociology, vol.26, pp.271-296.

Kathleen Gerson, Hard Choices, How Women Decide about Work , Career , and Motherhood University of California Press London, 1985 p.201 
L.C. Sayer, S.M. Bianchi, J.P. Robinson. Are parents investing less in children? Trends in mothers' and fathers'time with children American Journal of Sociology, 110 (1) (2004), pp. 1-43

Lois Wladis Hoffman , F.Ivan Nye (1986). Working Mothers, Jossey Bass Publishers 1975, London, p.9, http://www.garfield.library.upenn.edu/ classics1986/A1986A869300001.pdf

Maeve, O'Brien (2007). Mothers' Emotional Care Work in Education and its Moral Imperative, Gender and Education, 19:2, 159-177, DOI: $10.1080 / 09540250601165938$

Milkie, M. A. Mattingly, M. J., Nomaguchi, K. M., Bianchi, S. M. \& Robinson, J. P. (2004). The Time Squeeze: Parental Statuses and Feelings about Time with Children. Journal of Marriage and Family, vol.66, pp.139-161.

Milkie, M. A., Raley, S. \& Bianchi, S. M. (2009). Taking on the Second Shift: Time Allocations and Time Pressures of U.S. Parents of Preschoolers. Social Forces, vol.88, pp.487-517.

Mirza, Shazia. Women's employment, 2014. http://www.pakistangendernews.org/ womens-employment/. Retrieved on 22/Mar/2017.

Nomaguchi, K. M, Milkie, M. A. \& Bianchi, S. M. (2005). Time strains and psychological well-being: Do dual-earner mothers and fathers differ? Journal of Family Issues, vol.26, pp.756-792.

Poduval, J., \& Poduval, M. Working Mothers: How Much Working, How Much Mothers, And Where Is The Womanhood? Mens Sana Monographs, 2009, 7(1), 63-79. http://doi.org/10.4103/0973-1229.41799

Positive effects of working mothers. (2000, 04). USA Today, 128, 4-5. Retrieved from https://search.proquest.com/docview/214602417?accountid=135034

Rocío Sánchez-Mangas, Virginia Sanchez-Marcos Balancing Family and Work: The Effect of Cash Benefits for Working Mothers http://www.sciencedirect.com/science/article/pii/S0927-5371(07)00107-8

Sanchez-Mangas, Rocio \& Sanchez-Marcos, Virgina. Balancing family and work: The effect of cash benefits for working mothers, Labour Economics, 2008, Vol-15, Issue-6,pp. 1127-1142. 
Sayer, L. C, Bianchi, S. M. \& Robinson, J. P. (2004). Are Parents Investing Less in children? Trends in mothers' and fathers' time with children. American Journal of Sociology, 110, Maternal Employment and Child Care Decision.

Sayer, L. C. (2005). Gender, Time, and Inequality: Trends in Women's and Men's Paid Work, Unpaid Work, and Free Time. Social Forces, vol.84, pp.285303.

Schneider, B. (2006). In the Moment: The Benefits of the Experience Sampling Method. In M. PittCatsouphes, E. E. Kossek, \& S. Sweet (Eds.), The work and family handbook: Multi-disciplinary perspectives and approaches (pp. 469 - 488). Mahwah, NJ: Erlbaum.

Suzanne M. Bianchi and Melissa A. Milkie (June 2010). Work and Family Research in the First Decade of the 21st Century, Journal of Marriage and Family, Published by: National Council on Family Relations, Vol. 72, No. 3, pp. 705-725, http://www.jstor.org/stable/40732504

Wilson D. S. A. New Look at the Affluent Worker: The Good Working Mother in Post-War Britain, Twentieth Century British History, 2006, 17:206299. Available at: http://tcbh.oxfordjournals.org/cgi/content/full/17/2/206.

Dr. Shagufta Nasreen is an Assistant Professor in the Centre of Excellence for Women's Studies, University of Karachi.

Dr. Aliyah Ali is an Assistant Professor in the Centre of Excellence for Women's Studies, University of Karachi.

Dr. Faraz Ahmed Wajidi is an Assistant Vice President, Head of Research and Development (L\&MDD) National Bank of Pakistan. 